\title{
Heat Stress: A Threat to Health and Safety
}

\author{
Mohamed K. Yousef, Sueko SAGAWA and Keizo SHIRAKI \\ Department of Physiology, School of Medicine, University of Occupational and \\ Environmental Health, Japan. Kitakyushu 807, Japan
}

\begin{abstract}
This review offers a rational basis for the use of fundamental physiological controlling mechanisms in setting safe environmental limits for occupational situations where heat stress is encountered. There is no single index of heat stress that has been universally accepted. However, the use of wet bulb glove temperature (WBGT) has been adopted by various organizations on occupational health and safety in several industrial countries. Thermal limits suggested for everyday work continue to be subject to argument. The controversies arise from the fact that many factors such as individual variations, acclimatization, clothing, age, sex, physical fitness and work load lead to significant effects on tolerance of man to heat. Several measures for prevention of heat stress under industrial situations are summarized briefly. There is no agreement on a single measure to be used, rather a combination of these measures can be the most effective mean to alleviate or prevent severe heat stress. It is to be hoped that this review may help public health officials and medical doctors of various work occupations resolve some of the problems that arise in setting thermal limits and preventive measures, thus contributing to increase productivity and efficiency of work.
\end{abstract}

Key words: thermal stress, thermoregulation, WBGT, occupational health, thermal limit.

(Received 13 May 1986)

\section{Introduction}

Heat is perhaps the most prevailing thermal environment that man encounters either naturally or in his work place. A large portion of the earth's surface is found in the tropical, semi-arid, and arid regions. In these climatic regions, man is naturally exposed to heat stress (hot dry or hot humid) either at work or at rest at least during the summer season. In addition, there are many situations as in industry, i.e. mining, steel, glass, $\cdots$ etc., and in some occupational activities, i.e. firefighters and military personnel, where hot climate is experienced. Occupational heat disorders have been recognized since the dawn of industrialization in Europe and Japan (Telekey, 1948; Miura, 1977). In Japan, many picture scrolls produced during the Edo period in the 18th century are an ample evidence of severe heat stress in metal refineries where the workers wore "Koromo mushiro" (a protective clothing made of straw) and face shields of cloth to protect themselves (Miura, 1969, 1970, 1977). The levels of heat stress in various industries have been summarized recently (Mutchler \& Vecchio, 1977; Miura, 1978). Although technological advances and automechanization have made important strides in decreasing the 
severity of heat stress, it did not completely eliminate the threat to health and safety.

It is not unusual that in some mines of the world's temperate zones, i.e. Europe, the miners are exposed daily to a greater degree of thermal stress than can be found in some hot climatic regions. Regardless of where heat stress occurs, it has a detrimental effect on both health and work productivity (Leithead \& Lind, 1964).

In general terms, heat stress is defined as the combination of both climatic and non-climatic factors which either limit heat loss from the body or result in heat gain from the surroundings (Lind, 1977). The climatic factors include a combination of air temperature, relative humidity, wind, and radiant heat. The non-climatic factors include clothing, workloads, age, sex, etc. Physiological responses to heat stress usually reflect the severity and duration of exposure. Therefore, quantitative measurements of heat stress, of the consequent physiological responses, and the relationship of one to the other could be utilized to provide physiologists with data to assess the limits of heat stress allowable in various work situations and to find an efficient and an economically feasible way to reduce the level of heat stress. Additionally such data provide the fundamental scientific basis to industrial hygienists, engineers, medical doctors, and administrators to develop reasonable work loads and work patterns resulting in increasing productivity and safety of workers.

\section{Fundamentals of Thermoregulation in Hot Environments}

If body temperature is to remain relatively constant, metabolic heat production plus heat gain from the surroundings by physical means (convection, conduction, radiation) must equal heat loss. The basic principles of human thermoregulation have been well reviewed recently (Houdas \& Ring, 1982; Yousef, 1986). In general, metabolic heat production is dependent on work loads and heat gain is controlled by the gradient between the ambient thermal load and body temperature.

For a man of average size $(70 \mathrm{~kg})$, let us assume a basal metabolic rate of $60-70$ $\mathrm{kcal} / \mathrm{hr}$ and a metabolic heat production of $300 \mathrm{kcal} / \mathrm{hr}$ for a moderate work level. If we assume that this man's body fails to lose its heat, then at rest, he would produce sufficient heat to increase his body temperature by about $1^{\circ} \mathrm{C} / \mathrm{hr}$. However at the assumed moderate work level, his body temperature would rise at a rate of $5^{\circ} \mathrm{C} / \mathrm{hr}$. This simple calculation demonstrates the importance and efficiency of the heat loss mechanisms especially in situations where the combined metabolic heat production and heat gain by convection and radiation are at a much greater level than is presented in the above mentioned example. Whenever heat production exceeds heat loss, a rise in body temperature occurs leading to a possible heat disorder. Thus for one to develop a measure to alleviate heat stress in the work place, the energy cost of various jobs and tasks should be measured. If such measurement is not practical for a given situation, then the literature should be consulted. In Japan, the reader is referred to the comprehensive tables of 
energy expenditures for various occupations in practically every industry. The tables were compiled originally by the Subcommittee on Metabolic Rate of the Food and Nutrition Committee, Resources Council, Ministry of Science and Technology (1960) and additional data continue to be compiled by numerous exercise physiologists and nutritionists in Japan.

In hot environments, evaporation of sweat is the only significant avenue for heat loss to prevent the body from overheating. The rate of heat loss from the body depends on the gradients of temperature and water vapor pressure between the skin and its surroundings. These purely physical relations are affected by two physiological mechanisms: circulatory adjustments, specifically the vasomotor control, and sweating.

1. Circulatory adjustments

As the environmental heat load exceeds that of the comfort zone, blood flow to the periphery increases due to active vasodilation and to the release of the vasoconstrictor tone (Buskirk, 1981). Gutaneous vasodilation may result in an undesirable strain on circulation due to associated visceral vasoconstriction, i.e. splanchnic bed. Consequently, some heat disorders may be attributable to overload of the circulatory system which leads to circulatory failure. Obviously individuals with cardiovascular diseases of any sort are in hazard in hot climates and should not be employed in such conditions.

2. Sweating mechanism

Sweat is a hypotonic solution containing many solutes of which sodium chloride is the most important (Kuno, 1956). Rate of sweating increases to meet the requirement of cooling when thermal stress and workload increases (Adolph, 1947). Maximum sweat rate which can be maintained for a long period is estimated to be in the order of $2 \ell /$ $\mathrm{hr}$. The amount of salt loss per liter of sweat, on the average, is $2.0 \mathrm{~g}$ or about 15 $\mathrm{g} /$ day which is the approximate dietary intake for Europeans and Americans (Lee, 1964).

It should be realized that saltiness of sweat is extremely variable among any given group of men or women (Yousef, 1980). Therefore drinking water to replace body fluids lost in sweat may not be adequate for all individuals to maintain their body fluid homeostasis resulting in potential dehydration and its associated undesirable concentrations of body fluids (Yousef \& Davis, 1985; Smith \& Yousef, 1985). The volume of water drunk in dry hot environments was found to be less the saltier the sweat (Dill, 1985). In other words, water intake may be adjusted to the level required for maintaining a constant osmotic pressure of body fluids. With acclimatization to heat, the capacity to produce sweat increases, but saltiness of sweat decreases (Horvath, 1981). The practical application of this finding is to insure acclimatization of workers prior to their employment in a hot environment to reduce the risk of heat disorders and to increase productivity.

\section{Acclimatization to Heat}

In $1768, \mathrm{~J}$. Lind, recognized the value of acclimatization when he described the 
hazard to health of newcomers to the tropics and that habituation to hot environments decreases the danger to health. Nearly two hundred years later, this phenomenon became better understood and was termed acclimatization rather than habituation. Acclimatization to heat is defined as a series of physiological adjustments which decrease the intensity of heat stress upon exposure to hot environments. Heat acclimatization can be either "natural" as in the case of one who lives in hot climates or "artificial" as may occur by exposure to heat in climatic rooms. In either situation, the most important physiological adjustments include increased sweat rate, decreased heart rate, body temperature, and concentration of salt in sweat (Horvath, 1981).

Acclimatization to heat is more pronounced and occurs much faster in a man undertaking physical work as compared to his counterpart who is sedentary (Kielblock et al., 1982; Stewart, 1982). In other words, exercise is necessary for full acclimatization. To induce acclimatization, arrange for a single bout of exposure to heat while working at a moderate work level for 100 minutes per day for about 7-14 days. Most of the acclimatization occurs in the first $4-7$ days and complete acclimatization in $12-14$ days. A duration less than 100 minutes per day was less effective. Also if the 100 minutes per day was not given in a single exposure, i.e. if given as 2 separate exposures of 50 minutes each, the rate of acclimatization was slower. The rate of acclimatization is more rapid in physically fit individuals. Individuals on a low-salt intake $(5-6 \mathrm{~g} / \mathrm{day})$ exhibit a slow rate of acclimatization, however, a high-salt intake (above $15 \mathrm{~g} /$ day) does not speed up its rate. Acclimatization seems to be specific for the conditions of exposure, both the thermal environment and work loads. In other words, acclimatization to one level of work load and to a given hot environment do not provide acclimatization either for a heavier work load or a hotter environment.

In practice, arrange for workers to perform work similar to what is expected of them for 2 hours/day for about two weeks at a thermal environment equal to that of their work place. If the work load is very heavy, then use a two-stage procedure for acclimatization.

Data on decay rate of acclimatization resulting from absence in hot environments are not entirely in agreement. However, some experts agree that acclimatization to heat is retained for periods up to $9-14$ days after exposure and that thereafter the benefits are rapidly lost until it completely disappears in about one month.

\section{Occupational Heat Stress Measurement}

Several indices of heat have been developed to describe the stress imposed by a hot environment (Lee, 1980). There is no single index among all of these indices considered to be universally and fully acceptable. In the U.S.A., the National Institute for Occupational Safety and Health (NIOSH) in 1972 recommended the Wet Bulb Globe Temperature (WBGT) index as the standard heat stress index (NIOSH, 1972). Later, in 1975 
the Occupational Safety and Health Administration (OSHA) and in 1977, the American Conference of Governmental Industrial Hygienists (AGGIH) reemphasized NIOSH's recommendation (ACGIH, 1977; Ramsey, 1975). This index has been adopted in other countries, i.e. France, and it is described hereafter in detail.

Wet Bulb Globe Temperature (WBGT):

The WBGT index combines the effects of four main factors affecting heat stress: air temperature, wind velocity, humidity, and radiation heat (Yaglou \& Minard, 1957). The numerical value for the WBGT index is calculated as follows:

(a) For indoors

$\mathrm{WBGT}=0.7 \mathrm{WB}+0.3 \mathrm{GT}$

(b) For outdoors

$\mathrm{WBGT}=0.7 \mathrm{WB}+0.2 \mathrm{GT}+0.1 \mathrm{DB}$

where $\mathrm{WB}$, wet bulb temperature; GT, globe temperature and $\mathrm{DB}$, dry bulb temperature. The time weighted average WBGT is determined by the following equation:

Average $\mathrm{WBGT}=\left(\mathrm{WBGT}-\mathrm{t}_{1}+\mathrm{WBGT}-\mathrm{t}_{2}+\cdots+\mathrm{WBGT}-\mathrm{t}_{\mathrm{n}}\right) /\left(\mathrm{t}_{1}+\mathrm{t}_{2}+\cdots+\mathrm{t}_{\mathrm{n}}\right)$ where WBGT- $t_{1}, \cdots$, WBGT- $t_{n}$ are calculated for various work or rest areas occupied during the total time period; and $t_{1}, \cdots, t_{n}$ are the elapsed times spent in the corresponding areas. This index has been used with considerable success in reducing heat illness at military training centers, and its applicability for use in industry has been proven (Beshir, 1981). However the index has several shortcomings, primarily that its reliability is questioned when humidity is very high or very low.

\section{Thermal Limits for Different Types of Occupations}

There is a long history of debate among physiologists, public health officials, and medical doctors regarding the levels of heat and work to which industrial workers can be exposed without heat illness (Dukes-Dobos \& Henschel, 1973). An objective physiological criterion for establishing environmental limits of every day work has been proposed and named "Permissible Exposure Limits" or PEL (Lind, 1977; Dukes-Dobos, 1976). The PEL recommended by WHO in 1969 (WHO, 1969) were based on workers' deep body temperature which should not be permitted to exceed $38.0^{\circ} \mathrm{C}$, when exposed daily to heavy work in hot environments. Since the WBGT index does not consider work load levels as a factor, other indices were combined with the WBGT to identify the different combinations of climatic factors and work loads which $95 \%$ of an average acclimatized, healthy, and physically fit population of men could tolerate with body temperatures not exceeding $38^{\circ} \mathrm{C}$. This combined index is known as the "Threshold WBGT Levels" (Dukes-Dobos, 1976). A summary of the Threshold WBGT Levels for different work loads is shown in Table 1.

Modifications of threshold WBGT have been made to include factors such as unacclimatized, clothing, sex, and age. An example is shown in Table 2. 
Table 1. Threshold WBGT levels for men normally clothed, acclimatized, physically fiit, and in good health

\begin{tabular}{lc}
\hline Work load & WBGT, ${ }^{\circ} \mathrm{C}$ \\
\hline Light work $($ less than $200 \mathrm{kcal} / \mathrm{hr})$ & 30 \\
Moderate work $(201-300 \mathrm{kcal} / \mathrm{hr})$ & 28 \\
Heavy work $(301-400 \mathrm{kcal} / \mathrm{hr})$ & 26 \\
Very heavy work (above $400 \mathrm{kcal} / \mathrm{hr})$ & 25 \\
\hline
\end{tabular}

Table 2. Modification of threshold WBGT level

\begin{tabular}{lc}
\hline Condition & Modification of WBGT \\
\hline Unacclimatized & Subtract $2{ }^{\circ} \mathrm{C}$ \\
Unfit & Subtract $2{ }^{\circ} \mathrm{C}$ \\
Obese & Subtract $1-2^{\circ} \mathrm{C}$ \\
Old age & Subtract $1-2^{\circ} \mathrm{C}$ \\
Females & Subtract $1{ }^{\circ} \mathrm{C}$ \\
Clothing & \\
$\quad$ shorts or seminude & Add $2{ }^{\circ} \mathrm{C}$ \\
$\quad$ impermeable jackets & Subtract $2{ }^{\circ} \mathrm{C}$ \\
$\quad$ impermeable full-length coats & Subtract $4{ }^{\circ} \mathrm{C}$ \\
Increased air velocity above $1.5 \mathrm{mps}$, as long & Subtract $5{ }^{\circ} \mathrm{C}$ \\
as air temperature is below $35^{\circ} \mathrm{C}$ & Add $2{ }^{\circ} \mathrm{C}$ \\
\hline
\end{tabular}

\section{Tolerance Time for Work in Severely Hot Environments}

Unfortunately little information is available on tolerance time of workers involved in various types of occupations in hot environments. Data on a few studies under laboratory conditions simulating severe heat stress were summarized by Leithead and Lind (1964). They proposed the Oxford index as another measure of heat stress in extremely hot environments. The index is calculated by the following equation:

Oxford index $=0.15$ (dry bulb temp.) +0.85 (wet bulb temp.).

It must be emphasized here that the number of men studied in these experiments are relatively very few and that the question of acclimatization of these subjects was not fully addressed. In general, as the working load increases, the tolerance time decreases.

\section{Control of Heat Stress}

Available evidence indicates that when man works in very hot environments, his physiological and psychological efficiency decreases and consequently there is hazard to health. Several heat stress preventive measures have been used in industrial situations where heavy work was performed safely at an average WBGT of $34^{\circ} \mathrm{C}$, which is generally 
considered unacceptable work environment (Millican et al. 1981). There is no single preventive measure that can be used to alleviate or prevent excessive heat stress, rather a combination of measures can be very effective. The following is a brief summary of examples of control measures of heat hazard in an industrial setting:

1. Indoctrination of workers

All employees should be trained and educated in heat hygiene. This can be accomplished by the use of safety films, booklets, medical alerts, and regular sefety meetings. The employees should be familiar with the importance of preventing dehydration by frequent drinking.

\section{Acclimatization}

All employees should be heat acclimatized. Any worker away from work in hot areas for 2 weeks or more, should be reacclimatized or at least reminded to protect himself by more frequent breaks and receive more supervisory attention.

3. Medical Supervision

All employees should be given regular physical examinations and certified for work in hot environments. Individuals with a history of cardiovascular abnormalities, diabetes, obesity, and the unfit should not be allowed to work in hot areas and should be reassigned to different jobs.

4. Physical Fitness

A supervised physical fitness program should be instituted and all workers' levels of physical fitness should be measured periodically. The worker must be aware that decreased fitness means a loss in heat tolerance.

5. Availability of water and salt

A source of cool drinking water should be close to the work place. Either a small amount of salt (about $0.1 \%$ ) should be added to drinking water, or salt tablets should be available near the water. All workers should be encouraged to drink at least $200 \mathrm{ml} / \mathrm{hr}$.

6. Cool rooms

Have a cool, comfortable rest area near the work place which the workers can use during breaks. Fans are useless where air temperature is above $35^{\circ} \mathrm{C}$. Fans can be useful when used to force cool air (from a mobile air conditioner) from floor level to the higher and hotter work areas.

The use of a combination of the forementioned measures in addition to others can effectively reduce heat stress problems. In general an adequate program to alleviate heat stress should be based on three principles: a) take measures to reduce convective and radiative heat gain from the environment by the use of protective clothing, shielding, insulation, etc. b) take measures to increase evaporative potential by increasing general ventilation, using ventilated suits, etc. c) take measures to provide an average weighted WBGT between $27-29^{\circ} \mathrm{C}$ by modifying the restwork regimen. 


\section{Heat Disorders}

Heat illness is produced by metabolic and environmental heat that together constitute a load on the body. The clinical effect results from failure in the thermoregulatory mechanism, dehydration, and circulatory insufficiency in addition to other factors (Khogali \& Hales, 1983). The classification of heat disorders has been well described by Leithead and Lind (1964). They classified all incidences of heat disorders in three categories: (A) Disorders resulting from failure of thermoregulation. These include heat stroke and heat hyperpyrexia (synonyms: heat apoplexy, thermoplegia, hyperthermia, sunstroke, siriasis). Heat stroke occurs following sudden exposure to hot environment and is characterized by high body temperature (above $40.6^{\circ} \mathrm{C}$ ), absence of sweating, and disturbances of the nervous system. It is frequently fatal. Heat hyperpyrexia differs from heat stroke in that the victim is conscious, may be sweating, and the body temperature is usually lower.

(B) Disorders which result from and may complicate the thermoregulatory process. They include: 1) Circulatory instability (heat syncope). It occurs without observable depletion of water or salt resulting in giddiness, acute fatigue, or loss of consciousness. 2) Heat exhaustion. It is related to water or salt depletion. Water depletion is associated with thirst and pyrexia, leading to delirium and death. Salt depletion is associated with nausea, vomiting, giddiness, muscle cramps, and eventually circulatory failure. 3) Skin changes (prickly heat, anhidrotic heat exhaustion). It is a condition associated with prolonged wetting of the skin by sweat and a prickling sensation.

(C) Disorders related to psychological effects. These conditions are characterized by apathy or fatigue or by deterioration in performance of skilled tasks without any evidence of the entities listed above. Two recognized conditions are called mild heat fatigue (mild heat asthenia or acute heat neurasthenia) and chronic heat neurotic (chronic heat neurasthenia, tropical neruasthenia, tropical fatigue). The former condition is attributed to short and the latter to prolonged exposure to hot environment.

\section{Acknowledgment}

M. K. Yousef is on a sabbatical leave from the Desert Biology Research Center, University of Nevada, Las Vegas, Nevada 89154, U. S. A., a recipient of a fellowship award from the Japan Society for the Promotion of Science. This review was supported in part by NIH Grant No. IR 15 AG 06074-01.

\section{References}

Adolph, E. F. (1947): Physiology of Man in the Desert. Interscience, N. Y. 357 pp.

ACGIH. (1977): Threshold limit values for chemical substances and physical agents in the workroom 
environment with intended changes for 1977. Am. Conference of Governmental Industrial Hygienists.

Beshir, M. Y. (1981): A comprehensive comparison between WBGT and Botsball. Am. Ind. Hyg. Assoc. J. 42: 81-87.

Buskirk, E. R. (1981): Some current advances in the study of adaptations to exercise in the heat: body fluids and fluid loss. In: Environmental Physiology: Aging, Heat and Altitude. (Horvath, S. M.

\& Yousef, M. K., ed.), Elsevier/North-Holland, N. Y., p. 27.

Dill, D. B. (1985): The Hot life of Man and Beast. C. C. Thomas, Springfield, II.

Dukes-Dobos, F. N. (1976): Rationale and Provisions of the Work Practices Standard for Work in Hot Environments as Recommended by NIOSH. U. S. DHEW Publication No. NIOSH, 76-100.

Dukes-Dobos, F. N. \& Henschel, A. (1973): Development of permissible heat exposure limits for occupational work. ASHRAE. J., 15: 57-62.

Horvath, S. M. (1981): Historical perspectives of adaptation to heat. In: Environmental Physiology: Aging, Heat and Altitude. (Horvath, S. M. \& Yousef, M. K., ed.). Elsevier/North-Holland, N. Y., p. 11 .

Houdas, Y. \& Ring, E. F. J. (1982): Human Body Temperature. Its Measurement and Regulation. Plenum Press, N. Y. 256 pp.

Khogali, M. \& Hales, J. R. S. (1983): Heat Stroke and Temperature Regulation. Academic Press, Sydney. 312. pp.

Kielblock, A. J., Schutte, P. C. \& Strydom, N. B. (1982): Heat acclimatization; Prospectives and trends. J. Mine. Vent. Soc. (South Africa), 35: 53-62.

Kuno, Y. (1956): Human Perspiration. C. C. Thomas, Springfield, II.

Lee, D. H. K. (1964): Terrestrial animals in dry heat: man in the desert. In: Adaptation to the Environment. (Dill, D. B., Adolph, E. F. \& Wilber, C. C., ed.). Handbook of Physiology, Sec. 4. Am. Physiol. Soc., Bethesda, MD., p. 551.

Lee, D. H. K. (1980): Seventy-five years of searching for a heat index. Environ. Res., 22: 331-356.

Leithead, C. S. \& Lind, A. R. (1964): Heat Stress and Heat Disorders, F. A. Davis Co., Philadelphia.

Lind, A. R. (1977): Human tolerance to hot climates. In: Reactions to Environmental Agents. (Lee, D. H. K., Falk, H. \& Murphy, S. D., ed.). Handbook of Physiology, Sec. 9. Am. Physiol. Soc., Bethesda, MD., p. 93.

Lind, J. (1768): An Essay on Diseases Incidental to Europeans in Hot Climates. T. Becket, London.

Millican, R., Baker, R. C. \& Cook, G. T. (1981): Controlling heat stress-administrative versus physical control. Am. Ind. Hyg. Assoc. J., 42: 411-416.

Miura, T. (1969): Historical considerations on the hot environment in some industries. J. Sci. Labour, 45: $184-205$.

Miura, T. (1970): Occupational hazard due to heat and its prevention in some plants. J. Sci. Labour, 46: $771-779$.

Miura, T. (1977): A short history of occupational health in Japan. J. Sci. Labour, 53: 509-525.

Miura, T. (1978): Human performance under hot thermal condition of work environment. J. Human Ergol., 7: 157-168.

Mutchler, J. \& Vecchio, J. L. (1977): Empirical relationships among heat stress indices in 14 hot industries. Am. Ind. Hyg. Assoc. J., 38: 253-263.

National Institute for Occupational Safety and Health (1972): Criteria for a Reccommended Standard, Occupational Exposure to Hot Environments. U. S. DHEW, Publication No. NIOSH, HSM$72-10269$.

Ramsey, J. D. (1975): Heat stress standard: OSHA'S Advisory Committee Recommendations. Nat. Saf. News, 6: 69-78.

Smith, M. S. \& Yousef, M. K. (1985): Evaporative cooling of man running in desert heat. In: Seventh Conference on Biometeorology and Aerobiology. Am. Meteor. Soc., Boston, Mass., p. 258 
Stewart, J. M. (1982): Practical aspects of human heat stress. In: Environmental Engineering in South African Gold Miners, (Burrows, J. H. J., ed.). Cope and Transvaal Printers, Cape Town. p. 535. Subcommittee on Metabolic Rate of the Food, and Nutrition Committee of the Resources Council (1960): Relative Metabolic Rate of Industrial Work in Japan. Ministry of Science and Technology, Tokyo. Telekey, L. (1948): History of Factory and Mine Hygiene. Columbia Univ. Press, N.Y.

WHO (1969): Health Factors Involved in Working Under Conditions of Heat Stress. Geneva, WHO Tech. Rept. Ser., No. 412.

Yaglou, G. P. \& Minard, D. (1957): Control of heat casualties at military training centers. Arch. Ind. Health, 16: 302-316.

Yousef, M. K. (1980): Responses of men and women to desert heat. Intern. J. Biometeor., 24: 29-41. Yousef, M. K. (1986): Effects of climatic stresses on thermoregulatory processes in man. Experientia (in press).

Yousef, M. K. \& Davis, T. P. (1985): Fluid replacement in women during exercise in heat. In: Seventh Conference on Biometeorology and Aerobiology. Am. Meteor. Soc., Boston, Mass. p. 360.

\section{暑熱ストレス：高温職場環境での安全性}

Mohamed. K. Yousef ·佐川寿栄子・白木 啓三 産業医科大学第二生理学教室

要＼cjkstart旨：暑熱ストレスは人間が居住している自然環境下のみならず，鈗山や炭抗，あるいは製鉄所 に代表されるような高温職場環境に拈いてヒトの健康と安全を脅かす。ここでは高温環境 におけるヒトの一般的な体温調節機構を概説し, 高温作業環境での暑熱ストレスを防止す るためのいくつかの方法について言及した。 ヒトの耐暑性は, 個人差, 暑熱適応, 衣服, 年令, 性, 体力, 労作強度等により有意な影響を受けるので, 高温職場の許容温度は現在 な拉議論されている．環境の温熱条件を現わす示標として，WBGT (湿球黒球温度指数) が高温職場の評価や許容基準の判定に用いられている．労働衛生関係官打や産業医が，労 働の効率や生産性の上昇につながる職場環境の改善や高温の許容基準の設定を行う際に, 本総説が役立てば幸いである。

J. UOEH（産業医大誌），8（3)：355-364 (1986) 